\title{
Helen Kõmmus
}

\section{Viljandin kansanmusiikkifestivaalin runolauluesitysten reseptio Viron kirjoittavassa mediassa 2000-2006}

Viron runolaulua (vir. regilaul) on pidetty yhtenä Viron kansankulttuurin olennaisena piirteenä. Silti se on 1900-luvun lopusta lähtien, perinteistä kulttuuria nykypäivänäkin aktiivisesti käyttäviä Setumaata ja Kihnun saarta lukuun ottamatta, elänyt hiljaiseloa. Yllättäviä ja rohkaisevia runolaulun elpymisen merkkejä on Virossa laajemmin ilmestynyt viime vuosikymmeninä. Perinnekulttuurin nousevaa suosiota on tukenut runolaulun hyväksyminen suurille fuusiofestivaaleille ja erilaisiin musiikkiprojekteihin. Sitä kautta on se muuttunut median kiinnostuksen kohteeksi. Runolaulun uusi nousu, vaikkakin sekundaarisen perinteen muodossa, on tulossa osaksi nykykultuuria.

Vuodesta 1993 Viljandin kaupungissa Etelä-Virossa heinäkuussa järjestettävä Viljandin kansanmusiikkifestivaali (vir. Viljandi pärimusmuusika festival, eng. Viljandi Folk Music Festival) yhdistää perinteistä kansanmusiikkia ja nykyaikaisia musiikkityylejä. Festivaalin yhtenä keskeisenä tavoitteena on kautta vuosien silti pysynyt sekä virolaisen että muiden kulttuurien alkuperäisen musiikkiperinteen esittely ja opettaminen kansankulttuurista kiinnostuneelle yleisölle. Lyhyessä ajassa eli 15 toimintavuotensa aikana yhdeksi Viron merkittävimmistä musiikkifestivaaleista nousseessa nelipäiväisessä tapahtumassa oli vuoden 2004 kesällä noin 400 esiintyjää ja 20 000 kuulijaa (Kõmmus 2005: 118). Kyseessä on siis Viron kulttuurissa huomattava ja tutkimisen arvoinen foorumi.

Tässä artikkelissa keskityn tarkastelemaan Viljandin kansanmusiikkifestivaalin virolaisten runolauluesitysten reseptiota Viron kirjoittavassa mediassa, erityisesti sanomalehdissä, 2000-2006 välisellä ajanjaksolla.

\section{Media tutkimuskohteena}

Ajanjaksolta 2000-2006 Viron mediasta (sanomalehdet, televisio, radio, internetjulkaisut) löytyi 538 viittausta Viljandin festivaaliin. Näistä valitsin analyysiaineistoksi 94 sanomalehdissä ilmestynyttä artikkelia, joiden aiheena on Viljandin festivaalilla järjestetyt runolauluesitykset, sekä autenttiset että nykypäiväiset sovellukset. Autentisella runolauluesityksellä tarkoitan alkuperäiseen kansankulttuuriin liittyvää ja perinteisten sääntöjen mukaan esitettävää runolaulua, esimerkiksi setukaisten runolaulua. Sovelluksissa on kysymys runolaulun yhdistämisestä muiden nykyaikaisten musiikkityylien kanssa, esimerkiksi folkpop-yhtyeiden repertuaarin kanssa. 
Erityisesti kiinnitin huomiota eri teemavuosiin. Vuonna 2000 juhlittiin Viron runolaululle taidemusiikissa uuden ulottuvuuden antaneen säveltäjän Veljo Tormisin 70-vuotissyntymäpäivää, 2001 keskityttiin suomalais-ugrilaiseen musiikkiin, kesä 2002 oli omistettu perinnesoittimelle kanteleelle, 2003 festivaalin teemana oli laulu ja laulaja, 2004 soitettiin kansanomaisia puhaltimia, 2005 festivaalin teemana olivat jousisoittimet ja vuonna 2006 haitarimusiikki (Eesti Pärimusmuusika Keskus kotisivu 2007). Tämän tutkimuksen keskipisteeseen nousivat erityisesti vuodet 2000 ja 2003, jolloin runolaulu sai enemmän huomiota myös mediassa.

Koska tutkimuskohteenani ovat laulusta ja laulajista kirjoitetut tekstit ja niiden merkityssisällöt, koin olennaiseksi käyttää yhtenä tutkimusmenetelmänä diskurssi- eli puhetapa-analyysia (Katso Dijk 1998; Jokinen 2006, Holliday 2006). Lähestyin materiaalin analyysia siten, että kartoitin lehtiartikkeleista selkeimmin esiin nousevat aiheet ja valitsin niistä ne, joissa toimittaja on kuvannut runolaulun esitystä oman kokemuksensa pohjalta. Sen jälkeen toin kuvauksista esiin runoesitystä kuvaavia adjektiiveja ja ilmaisuja. Saatuja aihepiirejä ja sanastoa vertailin keskenään kuvauskohteen huomioon ottaen, esimerkiksi setukaisrunolaulun ja runorock-esitysten kuvauksia.

Aineiston lähteinä olleet sanomalehdet luokittuvat seuraavasti (Lehden nimen jäljessä on siitä saatujen artikkeleiden määrä ):

Päivälehdet: Postimees (18), Eesti Päevaleht (12);

Maakuntalehdet: Sakala (15), Maaleht (8), Virumaa Teataja (5), Pärnu Postimees (4);

Kulttuurilehdet : Sirp (8), Areen (6);

Iltapäivä- ja talouslehdet: SL Õhtuleht (8); Äripäev (5); Eesti Ekspress (5).

Eniten juttuja Viljandin festivaaleista julkaisivat kolme sanomalehteä: kaksi valtakunnallista, luetuinta isoa päivälehteä Postimees ja Eesti Päevaleht sekä Viljandin paikallinen lehti Sakala. Molemmilla päivälehdillä on kulttuuriliite ja siinä musiikkiin keskittynyt osa, jossa julkaistaan usein myös kansanmusiikkiaiheisia juttuja. Eesti Päevaleht on ollut monta vuotta myös Viljandin festivaalin virallinen tukija. Vuonna 2004 ilmestyi myös festivaalille omistettu 8-sivuinen erikoisliite. Viljandin maakuntalehdessä Sakalassa on pääasiassa festivaalia koskevia uutisia. Päivälehdissä julkaistaan uutisten lisäksi myös analyyttisia ja kriittisiä tekstejä. Kulttuurilehdissä on esillä tapahtuman musiikilliselle ja kultuuriselle sisällölle keskittyneitä pohdintoja. Iltapäivälehdet ja myös talouslehdet nostavat esille tapahtuman viihteellisen puolen. 


\section{Ketkä kirjoittavat}

Aiheesta kirjoittivat monet journalistit. Yhteensä analysoin tarkemmin 21 toimittajan juttuja. 15 lyhyempää uutistekstiä olivat anonyymejä. Enemmän Viljandin festivaalin aiheista kiinnostuneita oli pari toimittajaa.

Kirjoittajia oli kahdenlaisia: tutkijat ja musiikkikriitikot, jotka kirjoittivat runolaulun olennaisista piirteistä, ja toimittajat, jotka antoivat yleiskatsauksia musiikkitapahtumista.

Yksi kiinnostavimmista ja arvostetuimmista kirjoittajista oli Viron ensimmäinen etnomusikologian tohtori Vaike Sarv ${ }^{1}$, joka keskittyi erityisesti setukaisten runolauluun.

Toinen merkittävä kirjoittaja on musiikkikriitikko Avo Kartul, joka on Tarton yliopiston kirjaston musiikkiosaston johtaja. Hän on analysoinut objektiivisesti, mutta tavalliselle lukijalle helposti ymmärrettävässä populaarissa muodossa vanhakantaisen laulukerrostuman, erityisesti runolaulun, ja nykypäiväisen musiikkimaun kontakteja. Sarv ja Kartul ovat julkaisseet laadukkaita runolauluaiheisia pohdintoja pääasiassa kulttuurilehdissä ja päivälehdissä.

Kolmas kiinnostava ja edellisistä poikkeava toimittaja on semiootikko Ott Heinapuu, joka julkaisee eri tyylisiä juttuja eri suuntaisissa, sekä kultuuri- että kaupallisissa lehdissä. Hänen eräs lempiaiheensa on autenttinen miesten laulu ja ns. runorock, josta hän on antanut ytimekkäitä konserttikuvauksia.

\section{Sanoma vai lavashow}

Aineistoa lukiessa herää kysymys, mikä tulee runolauluaiheesta kirjoitettaessa enemmän esille, esityksen sisällöllinen taso eli musiikin rakenne, sanoma, vaikutus, laulajan vokaaliset ominaisuudet ja mestarillisuus vai esityksen ympärille rakentuva muodollinen kehys.

Sisäisen tai ulkoisen korostaminen riippuu selvästi sanomalehden profiilista ja lukijakohderyhmästä. Erityisesti siitä, miten tärkeä osuus on mainonnalla. Iltapäivälehdet, esimerkiksi SL Õhtuleht, talouslehdet, esimerkiksi Äripäev, sekä myös muutamat maakuntalehdet, esimerkiksi Sakala, antavat mahdollisimman monipuolisen ja yleisen kuvan tapahtumasta ja tuovat ennen kaikkea esille lauluesityksen viihteellisyyden. Tavoitteena on antaa lukijalle kiireiseen päivään nopea ja tehokas rentoutumishetki. Luodaan kuva runolaulusta tuotteena, jota on helppo käyttää joka tilanteessa häirisemättömänä taustana ja joka ei vaadi erikseen kallista aikaa eikä keskittymistä. Kiinnos-

1 Vaike Sarv väitteli vuonna 2000 Tampereen yliopiston musiikintutukimuksen laitoksella. Valitettavasti hänen setukaislaulun tutkimuksensa ja muu toimintansa jäi kesken kohtalokkaan sairauden takia vuonna 2004. 
tuksen keskipisteessä ovat yhtyeet kokonaisuudessaan, niiden tyyli ja imago, vaikutus yleisölle. Esintyjien nimiä mainitaan ohimennen ja silloinkin yhtyeen tai tärkeimpien johtajien nimiä. Laulajat ja muut muusikot jäävät usein anonyymeiksi viihdyttäjiksi. Esimerkkinä on juttu Sakala-lehdestä. Konsertin tärkein osa näytti sen mukaan olevaan yleisön kokema tunnelma. Musiikin taso oli selvästi toisella sijalla.

Edellisen kansanmusiikkifestivaalin suurimmaksi elämyksekseni muodostui Ugalan (Viljandin teatteri, kirjoittajan täsmennys) salissa pidetty konsertti, jossa pääosassa olivat virolaiset miehet. Mitään niin hyvää ja omaa en ole kuullut aikoihin. En tarkoita tällä niinkään alkuperäistä kansanmusiikkia, vaan juuri sitä tunnelmaa, joka tuli lavalta yleisölle. On pakko sanoa, että vaikka oli hetkiä, jolloin nämä ammattimuusikot ihan vain nauttivat itsestään ja olostaan ja päästivät laulun hetkeksi otteestaan, he pitivät silti yleisön tiukasti hyppysissään. (Tulp 2004: 2) ${ }^{2}$

Kultturilehti Sirpin ja Postimees-päivälehden kulttuuriliite voivat sallia itselleen keskittymisen kulttuurin sisältöön. Yleistä on, että esitetään yhden laulajan ja hänen tyylinsä kuvailu festivaalin ja perinteisen musiikkikulttuurin puitteissa. Tuodaan esille hänen musiikilliset ominaisuutensa ja erikoisuutensa tai yhteensopivuutensa muihin verrattuna. Yhtyeen tai kuoron musiikkityyli ja lavakäytös saa merkityksensä yksilön kautta. Hyvä esimerkki on Vaike Sarven kommentti Sirp-lehdessä vuodesta 2001, missä hän vertaile eri runolaulutyylejä ja esittäjiä.

\footnotetext{
Vapaimmin käyttävät runolaulua tunteittensa ja ajatustensa ilmaisemiseksi ehkä Johansonien esitykset (virolainen populaarisessa muodossa runolaulua esittävä perhe, kirjoittajan täsmennys): he ottavat sanan sieltä, toisen tuolta, kommentoivat samalla omia lauluyhdistelmiään ja tekevät kaikenlaisia temppuja osoittakseen, että runolaulu rulettaa. Totta on, että Ugalan teatterin sali tule tupaten täyteen, mörisee mukana eikä haluaisi mitenkään lähteä pois. Toista mahdollisuutta demonstroi Oort-yhtyeellään Synterin Sassi, joka hioo "runorockin" linjaa. Viron kansanrunousarkistosta kaivamaansa alkusoinnullista runolaulua hän ei erityisemmin muuta, mutta koristelee sitä kitaralla ja säkkipillillä, ja traagisimmissa osissa liittää musiikkiin käyrätorven huutoa. (Sarv 2001: 4)
}

\section{Aitous konserttilavalla}

Sanomalehtijuttujen perusteella luokittuvat runolaulua esittävät tai sitä käyttävät esiintyjät seuraavasti:

1) autenttiset eli traditionaalisessa kulttuurissa varttuneet ja perinnettä jatkavat muusikot:

a) luojat, perinteen sääntöjen mukaan improvisoijat. Esimerkiksi setumaalainen miesten laulukuoro Liinatsuraq.

b) säilyttäjät. Arkistonauhoituksilta opitun musiikin muuttamaton esittäminen. Esimerkiksi tarttolainen naisten runolaulukoro Väike Hellero.

2 Lainaukset on käännetty virosta. 
2) autenttisemmat eli perinettä hyviin tunteevat, mutta sitä valinnaisesti käyttävät muusikot, perinteen tyylinmukaiset sovitukset: akustiset välineet, vokaalisuuden osuus suurempi. Esimerkiksi runolaulua improvisoiva ja akustisesti säestävä Laudaukse kääksutajad (Navetan oven vinguttajat),

3) folkpop-(rock-)muusikot, perinteen suuremmat sovitukset: sekoittaminen toisten tyylien kanssa, fuusiomusiikki, äänentoistolaitteiden suuri osuus, instrumentaalisuuden osuus suurempi, esimerkiksi folkpop-yhtye Vägilased.

4) klassisen koulutuksen saaneet ammattilaiset laulajat ja säveltäjät. Esimerkiksi Viron Akateeminen Mieskuoro, runolaulua aineistona käyttävät säveltäjät Veljo Tormis ja Märt-Mattis Lill.

Vaikkakin festivaalilla on joka kesä myös aitoja runolaulun taitajia sekä Setumaalta että Kihnusta, päätyvät lehtikirjoitusten kohteiksi selvästi enemmän perinnettä sovittavat yhtyeet kuin perinteiset laulajat. Viljandin festivaalilta tullaankin ennen kaikkea etsimään vanhan ja uuden musiikkikulttuurin symbioosia. Perinteiset muusikot saavat päähuomion muilla, aitoutta vaativilla kansanmusiikkifestivaaleilla, joissa he ovat pääesintyjiä, esimerkiksi vuodesta 1987 toimivalla Baltican kansanmusiikkifestivaalilla Virossa, Latviassa ja Liettuassa. Viljandin festivaalilla ovat perinteistä runolaulua taitavat setukaiset ja kihnulaiset ns. täydentämässä kokonaiskuvaa. Se näkyy myös mediassa. Perinteisiä runolaulun esityksiä ei kritisoida koskaan. Syynä näyttää olevan pääasiassa se, että nykyaikaiset yleissivistyneet toimittajat eivät tunne vanhaa runolauluperinnettä niin hyvin, että uskaltaisivat sanoa sen sisällöstä mitään olennaista. Yleensä naispuolisista autenttisista laulajista kyllä kirjoitetaan tunnustavasti, mutta heille ei omisteta kokonaista artikkelia. Sanat Kihnu ja Setu esiintyivät tutkitun aineston otsikoissa kumpikin vain kerran.

Lehtimiesten asema helpottuu heti, jos kuvaan liittyy nykyaikaisen musiikin piirteitä. Lyhyet kommentit muuttuvat pitkiksi kuvailuiksi. Median lempiaihe näyttää olevan voimakkaiden miesäänisten rockbändien runolaulusovitukset. Esimerkiksi ovat Virumaa Teataja-lehden toimittajat samassa jutussa mainineet setukaisia perinteisiä naislauljia selvästi neturaalisellä sävyllä ja kontrastina siihen kuvaillut setukaisnuorten folkrock bändiä aika vapaasti ja ytimekkäästi.

Paikalla olivat setukaisnaiset, tunnetusti hyvin aitoina. Virolaisista yhtyeistä herättivät lisäksi huomiota nuorista soittajista koostuva Zetod, joka laulaa mukaansatempaavasti oman kotiseutunsa lauluja sekoittaen niihin rockia ja punkia. Mainiota oli nimenomaan näiden nuorten miesten elämänilo, positiivinen esiintyminen ja vauhdikas musiikki, jonka mukaan saattoi hyvin tanssia. (Klaas 2006: 3) 


\section{Liinatsuraq ja Vägilased}

Seuravassa tarkastelen kahden Viron mediassa eniten huomiota saaneen yhtyeen, perinteisen setukaisruonolaulukuoron Liinatsuraq (Kaupunkilaispojat) ja runolaulua sovittavan folkpop-yhtyeen Vägilased (Sankarit) reseptiota sanaston tasolla.

Perinteistä runolaulajaa kuvaavat adjektiivit ja ilmaisut liittyvät usein laulajan esityksen ja tyylin luonnehtimiseen. Yleinen ilmapiiri ja yleisö on toisella sijalla.

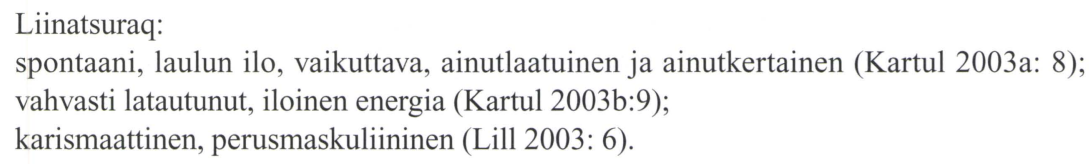

Runolaulutyylisen folkpop-esityksen kuvailu keskittyy siihen, miten runolaulufuusiot vaikuttavat yleisöön ja konsertin ilmapiiriin. Esiintyjä on osa kokonaisuutta. Esimerkiksi folkpop-yhtyettä Vägilased kuvaillaan jatkuvasti yleisöön tehdyn vaikutuksen kautta. Vaikka solisti Meelika Hainsoo on usein saanut tunnustusta hyvästä virolaisen runolaulun tyylin ymmärtämisestä ja esittämisestä, se ei tule yhtyeen konsertin kuvailusta kertaakaan esille. Artikkeleissa korostetaan vain kokonaisuutta.

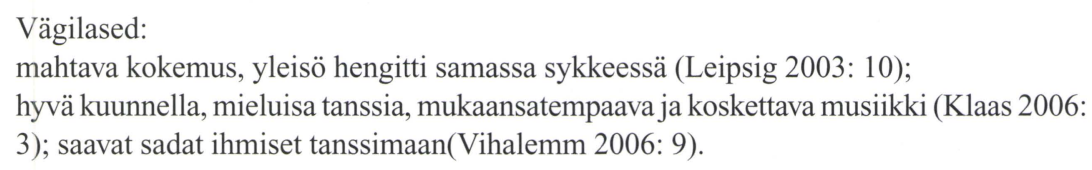

\section{Yksilöllisyys versus yhteisöllisyys}

Tekstien ohella on kiinnostavaa seurata, miten konserttitilannetta ja laulajia on esitetty artikkeliin liittyvissä valokuvissa. 94 artikkelista 49:ssä eli yli joka toisessa oli mukana 1-3 valokuvaa. Kuvia oli enemmän päivälehdissä ja iltapäivälehdissä. Kulttuurilehdissä ja maakuntalehdissä oli pääasiassa keskitytty tekstiin.

Kasvot ja yksityiskohdat ovat esillä runolaulusolistien ja -kuorojen valokuvissa. Vaikka lavalla on iso kuoro, keskittyy valokuva persoonallisuuden esille nostamiseen. Kuvan kautta korostetaan jokaisen laulajan olennaisuutta, erikoisuutta ja individuaalisuutta. Musiikkiin yritetään päästä sisälle laulajan ilmeiden ja käyttäytymisen esiin tuomisen kautta. Näin siirrytään ns. yksityiskohdasta yleiseen eli yleistä ilmapiiriä, kontekstia selvitetään osan, esimerkiksi laulun tai esittäjän kautta. Ensisijalla on henkilökohtaisuus, tekijyys, luovuus.

Yleiskuvat ja ilmapiiri dominoivat kuvissa, jotka on otettu runoa ja rockia yhdistävistä fuusiomaisista yhtyeistä. Yritetään saada kaikki erilaisuudet samaan kuvaan. Suosittu aihe on esiintyjien ja yleisön kontakti, esimerkiksi samaan tahtiin lavalla ja aukiolla liikkuvat ihmiset. Yleisön reseptiosta etsitään vahvistusta esiintyjien arvok- 
kuudelle. Kyseessä on ns. yleisestä yksityskohtaan eli kokonaiskuvan, kontekstin kautta tiedostetaan yksityiskohtien paljous ja kirjavuus.

\section{Yhteenveto}

Runolaulu on lähettiläs maailmasta, jossa vallitsivat nykyaikaamme verrattuna toiset esteettiset ja kulttuuriset säännöt ja mahdollisuudet. Ihmisillä oli aikaa keskittyä yksityiskohtiin. Vaikkapa improvisoida ja keksiä, miten saman asian voi sanoa ja laulaa esimerkiksi runolaulun säepareissa eri tavalla monta kertaa.

Kun runolauluun liitetään nykyaikainen rytmi ja melodia, niin sekä laulajien että yleisön huomio siirtyy yhdestä yleiseen, yksilöllisyydestä yhteisöllisyyteen. Tällaisen muutoksen huomaamiseen antaakin parhaan mahdollisuuden median reseption tutkiminen, tässä tapauksessa Viljandin kansanmusiikkifestivaalin seuraaminen Viron lehdistössä ilmestyneiden kirjoitusten ja valokuvien kautta. Tutkimuksessani selvisi, että autenttisia runolauluesityksiä kuvaillaan yksilön ja individuaalisuuden kautta. Runolaulun nykyaikaisia sovituksia esitellään sen sijaan yleisen ilmapiirin kautta.

Lopuksi voi myöntää, että medialla on huomattava osuus runolaulun paluussa kansan pariin. Tiedotusvälineet ovat avoinna popkulttuurille, josta on kiinnostunut Viron aktiviisimmin kuluttava, 20-40-vuotiaiden sukupolvi. Viljandin festivaalin suosion kautta ovat radiossa, internetissä, sanomalehtien palstoilla ym löytäneet paikkansa kansanmusiikia nykypäivänä suosittujen tyylien kanssa sovittavat popbändit. Sovitusten kautta nuori kuuntelija saa kokemuksen myös runolaulun meditatiivisista melodioista ja rikkaista teksteistä. Se herättää kiinnostusta omia juuria kohtaan. Monet nuoret virolaiset ovat juuri mediassa esillä olevien kansanmusiikkisovitusten kautta innostuneet etsimään käsiinsä ja laulamaan yhdessä alkuperäisiä runolauluja. Se näkyy selvästi Viljandin festivaalin katukuvassa, missä on vuosi vuodelta yhä enemmän spontaania kansanlaulujen laulamista. Perinteisen laulumuodon elpyminen nykymusiikin vaikutteisessa maailmassa todistaa, että runolaulu on Viron kulttuurin perustassa vahvasti ja elinvoimaisesti tallella. 


\section{Lähteet}

Dijk, Teun Adrianus van (1998) Ideology : a multidisciplinary approach. London: Sage

Holliday, Adrian, Hyde, Martin \& Kullman, John (2006) Intercultural Communication. An Advanced Resource Book. - Routledge Applied Linguistics. Editors Candlin, Christopher N \& Carter Roland. London and New York: Routlege, Taylor \& Francis Group

Jokinen, Arja, Juhila, Kirsi \& Suoninen, Eero (2006). Diskurssianalyysi liikkeessä. Tampere: Vastapaino

Kõmmus, Helen (2005) Kaustise rahvamuusikafestival ja Viljandi pärimusmuusikafestival: võrdsed, ent võrreldamatud? - Pärimusmuusikast populaarmuusikani. Töid etnomusikoloogia alalt 3. Tartu: Eesti Kirjandusmuusemi etnomusikoloogia osakond. Ss 99-120.

Lehtiartikkelit

Kartul, Avo (2003a) Seto meeste laul kõlab võimsalt. Postimees, 23.07, ss. 8.

Kartul, Avo (2003b) Kommentaar: Energialaengud esimeselt Viljandi folgipäevalt. Postimees, 26.07, ss. 9.

Klaas, Eva \& Lainvoo, Linda (2006) Kultuur: Viljandi folk meelitas kümneid tuhandeid muusikasõpru. Virumaa Teataja, 26.07, ss. 3 .

Leipsig, Krista \& Annuk, Sille (2003) Neli päeva täis laulu, tantsu ja õppimist. Postimees, 28.07, ss. 10.

Lill, Märt-Matis (2003) Folk ja tema publik. Postimees, 24.07, ss. 6.

Sarv, Vaike (2001). Regilaul püsib pinnal. Sirp, 17.08, ss. 4.

Tulp, Ene (2004) Õige folgifestivali tunne. Sakala, 27.07, ss. 2.

Vihalemm, Johanna-Mai (2006) Festival: kampsunimaigulisuse asemel linlikkus. Eesti Päevaleht, 24.07, ss. 9.

Internet-lähteet

Eesti Pärimusmuusika Keskus kotisivu (2007) „Eelmised festivalid“

http://www.folk.ee/festivalid (luettu 1.05.2007) 